\title{
PENGARUH PENGEMBANGAN KARIR DAN MOTIVASI KERJA TERHADAP KEPUASAN KERJA SERTA DAMPAKNYA PADA KINERJA PEGAWAI DI BADAN PENDAPATAN DAERAH (BAPENDA) KABUPATEN KARAWANG
}

\author{
Oleh : \\ Ahmad Yani \\ Universitas Singaperbangsa Karawang \\ email : a.yani.krw@gmail.com
}

\begin{abstract}
The purpose of this study to obtain empirical evidence and to find clarity of phenomena and conclusions about the influence of career development and job motivation to job satisfaction and its impact to the performance of employee at Badan Pendapatan Daerah (Bapenda) Kabupaten Karawang.

This research is expected to contribute to the development of management science especially as a contribution of scientific literature in human resources management, as reference material in scientific writing, as information material, both for leaders and colleagues in Badan Pendapatan Daerah Kabupaten Karawang in the implementation of performance-based management, As a material consideration and input in making decisions and determine the direction of policy.

The research is done by using quantitative method with descriptive and verification method, that is collecting, presenting, analyzing and doing hypothesis testing, and making conclusion and suggestion.

Based on the results of the research analysis, the following conclusions are obtained: the correlation of career development with work motivation has significant correlation, the influence of career development that directly affects employee job satisfaction, the influence of work motivation that directly affects employee job satisfaction, the influence of career development that directly affect the performance of employees, the influence of work motivation that directly affect the employee performance, the influence employee job satisfaction on employee performance, simultaneously career development and work motivation significantly influence employee job satisfaction, simultaneously career development and work motivation significantly influence job satisfaction which impact on employee performance improvement.
\end{abstract}

Keywords: career development, work motivation, job satisfaction, employee performance

\section{Pendahuluan}

Tujuan reformasi birokrasi yaitu untuk meningkatkan aparatur yang memiliki integritas dan kinerja yang tinggi, kompeten, profesional dan sejahtera, hal yang berkaitan dengan Sumber Daya Manusia, khususnya mengenai kepegawaian telah diatur oleh Undang-undang Nomor 43 Tahun 1999 tentang Pokok-Pokok Kepegawaian dan seiring perkembangannya dikeluarkan Undang-Undang Republik Indonesia Nomor 5 Tahun 2014 Tentang Aparatur Sipil Negara (ASN) sebagai pengganti Undang-Undang Nomor 43 Tahun 1999 tentang Pokok-Pokok Kepegawaian, dimana dalam undang-undang ASN lebih 
menitikberatkan pelaksanaan cita-cita bangsa dan mewujudkan tujuan negara, yaitu untuk membangun Aparatur Sipil Negara yang memiliki integritas, profesional, netral dan bebas dari intervensi politik, bersih dari praktik korupsi, kolusi, dan nepotisme, serta mampu menyelenggarakan pelayanan publik bagi masyarakat dan mampu menjalankan peran sebagai unsur perekat persatuan dan kesatuan bangsa berdasarkan Pancasila dan UndangUndang Dasar Negara Republik Indonesia Tahun 1945, Undang-Undang ASN mengubah manajemen Aparatur Sipil Negara yang berdasarkan pada perbandingan antara kompetensi dan kualifikasi yang diperlukan oleh jabatan dengan kompetensi dan kualifikasi yang dimiliki calon dalam rekrutmen, pengangkatan, penempatan, dan promosi pada jabatan sejalan dengan tata kelola pemerintahan yang baik.

Sesuai denganPeraturan Pemerintah Nomor 13 Tahun 2002 Tentang Perubahan Atas Peraturan Pemerintah Nomor 100 Tahun 2000 Tentang Pengangkatan Pegawai Negeri Sipil Dalam Jabatan Struktural menyebutkan bahwa polakarier adalah pola pembinaan Pegawai Negeri Sipil yang menggambarkan alur pengembangan karier yang menunjukkan keterkaitan dan keserasian antara jabatan, pangkat, pendidikan dan pelatihan jabatan, kompetensi, serta masa jabatan seseorang Pegawai Negeri Sipil sejak pengangkatan pertama dalam jabatan tertentu sampai dengan pensiun. Dengan memperhatikan faktor senioritas dalam kepangkatan, usia diklat jabatan dan pengalaman.

Pengembangan karier sangat erat kaitannya dengan kinerja pegawai. Pegawai akan menghasilkan kinerja yang lebih baik dalam bekerja karena ingin mencapai tujuan yaitu pengembangan karier. Seperti yang diungkapkan Kusnadi (Syafitri, 2010: 42) yang mengatakan "Karyawan akan menghasilkan kinerja yang baik apabila mereka memiliki motivasi pribadi yang tinggi, setiap motif ditandai dengan keinginan yang kuat untuk mencapai jenis target tertentu seperti pengembangan karir."

Hasil prasurvey mengenai pengembangan karir di Badan Pendapatan Daerah Kabupaten Karawang yang diberikan kepada 20 orang responden, menunjukan bahwa pengembangan karir pegawai masih belum optimal, itu terlihat pada hasil jawaban responden dengan pilihan jawaban TIDAK sebanyak 3 pernyataan dari total 5 pernyataan yang diajukan.

Selain dari pola pengembangan karir, produktivitas pegawai senantiasa menjadi fokus Badan Pendapatan Daerah Kabupaten Karawang untuk terus ditingkatkan demi mendukung kelangsungan tugas dan pencapaian target kinerja badan yang optimal.Pencapaian tersebut jelas didorong oleh dorongan atau motivasi yang kuat dari tempat dimana pegawai bekerja.

Hasil wawancara dengan Kepala Sub Bagian Kepegawaian Bapenda Kabupaten Karawang, motivasi dipengaruhi oleh banyak faktor, Fungsi organisasi yang dijalankan dengan baik akan melahirkan motivasi pegawai yang baik sehingga meningkatkan kinerja setiap pegawai adapun data prasurvey motivasi kerja pegawai dapat disimpulkan bahwa motivasi kerja pegawai berada pada kategori jawaban responden YA. Kebutuhan akan berprestasi berada pada kategori jawaban reponden TIDAK, hal ini menunjukan bahwa tingkat kemampuan untuk mencapai hubungan kepada standar perusahaan yang telah ditentukan serta perjuangan pegawai menuju keberhasilan belum bisa diperhatikan secara maksimal oleh organisasi atau bidang kepegawai dilingkungan Badan Pendapatan Daerah (BAPENDA) Kabupaten Karawang.

Mengacu pada teori dua faktor Herz Berg atau yang dikenal dengan teori motivasi dua faktor, dalam teori ini terdapat istilah dissatisfier-satisfier.Pada kondisi dissatisfer (higiene) terjadi apabila adanya rangkaian kondisi ekstrinsik, konteks pekerjaanyang menimbulkan ketidakpuasanantar pekerja bila kondisi tersebut tidak ada, jika kondisi tersebut ada, tidak selalu memotivasi pekerja.Pada kondisi ini faktor-faktor itu diperlukan hanya untuk mempertahankan, setidaknya satu tingkat dari tidak ada kepuasaan kerja. 
Kepuasan kerja menunjukkan sifat yang didasarkan pada penilaian dari berbagai aspek yaitu tugas, keadaan pekerjaan, dan hubungan antar pegawai.Kepuasan kerja yang tinggi menunjukkan bahwa sebuah organisasi telah mengelola kebutuhan karyawan dengan baik melalui manajemen yang efektif. Sementara itu, Luthans (2006) menyatakan bahwa kepuasan kerja adalah tergantung kepada bagaimana persepsi individu seseorang dalam melaksanakan tugasnya di tempat kerja sehingga bersifat subjektif bagi individu yang merasakannya. Pegawai akan merasa puas dalam bekerja apabila aspek pekerjaan dan individunya saling menunjang sehingga dapat dikatakan bahwa kepuasan kerja berkenaan dengan perasaan seseorang tentang menyenangkan atau tidaknya pekerjaan karyawan.

Data pra survei yang diberikan kepada 20 orang pegawai Badan Pendapatan Daerah Kabupaten Karawang mengenai kepuasan kerja dapat disimpulkan bahwa mayoritas dari responden mempersepsikan kepuasan kerja pada kategori cukup baik dilaksanakan karena rata-rata responden menjawab pada pilihan YA.Namun terdapat indikator atau pernyataan responden yang menjawab paling banyak pada piklihan TIDAK/lemah pada kepuasan kerja adalah tingkat pemberian insentif/Tunjangan Penghasilan Pegawai (TPP) dengan jumlah 15 responden dari total 20 orang responden.

Menurut Cardoso, dikutif Mangunegara $(2004 ; 67)$ dikatakan bahwa kepuasan kerja merupakan salah satu faktor yang mampu meningkatkan kinerja pegawai.Salah satu penentu tinggi rendahnya kinerja adalah kepuasan kerja pegawai itu sendiri, Kepuasan kerja merupakan salah satu elemen kerja yang penting bagi meningkatkan prestasi dan pencapaian sebuah organisasi.Kepuasan kerja dikatakan Wexly dan Yukl dalam kalimat "the way an employee feels about his or job" kepuasan kerja adalah cara pekerja merasakan dirinya dan pekerjaannya. Perasaan puas dalam bekerja ditunjukkan dengan sikap positif terhadap pekerjaan dan yang dihadapi dilingkungan kerjanya, kepuasaan ini terjadi apabila kebutuahan individu sudah terpenuhi sesuai derajat kesukaan atau ketidaksukaan.Ketika pegawai sudah merasakan kepuasan dalam bekerja, maka secara langsung mampu akan meningkatkan kinerja pegawai itu sendiri.

Menurut Mangkunegara(2004:67) bahwa kinerja adalah hasil kerja secara kualitas dan kuantitas yang dicapai oleh seorang pegawai dalam melaksanakan tugasnya sesuai dengan tanggung jawab yang diberikan kepadanya.Kemudian Donnely, Gibson, dan Ivancevich (Rivaiet al,2005: 15) menyatakan bahwa kinerja merujuk kepada tingkat keberhasilan dalam melaksanakan tugas serta kemampuan untuk mencapai tujuan yang telah ditetapkan. Kinerja dinyatakan baik dan sukses jika tujuan yang diinginkan dapat tercapai dengan baik.

Untuk mengukur keadaan kinerja pegawai Badan Pendapatan Daerah Kabupaten Karawang digunakan metode survey. Hasil pra survey yang dilakukan peneliti sebanyak 30 orang aparatur yang diambil secara acak tentang kinerja aparatur pada Badan Pendapatan Daerah Kabupaten Karawang, masih terdapat aspek yang lemah yaitu mengenai tingkat kerja sama antar pegawai, adanya komunikasi yang kurang lancar, baik komunikasi yang terjadi sesama pegawai ataupun komunikasi antara bawahan dan pimpinan. Hal ini terlihat dari beberapa fenomena seperti dalam memberikan tugas, pimpinan terkadang menganggap sepele dengan tugas yang diberikan tanpa bertanya sudah dimengerti atau belum pegawainya, dan atau mungkin pemimpin memberi tugas tidak sesuai dengan minat bakatnya hanya menganggap pegawainya harus melaksanakan tugas yang diberikan.

Melihat uraian di atas, mengacu pada fenomena-fenomena yang terjadi di lapangan serta mengingat betapa pentingnya pengembangan karier, motivasi, kepuasan kerja sebagai upaya untuk meningkatkan kinerja pegawai, dan penelitian inipun merupakan penelitian yang pertama yang dilakukan di Badan Pendapatan Daerah Kabupaten Karawang,dan peneliti tertarik untuk mengkaji secara mendalam mengenai "pengaruh pengembangan 
karir dan motivasi kerja terhadap kepuasan kerja serta dampaknya pada kinerja pegawai di Badan Pendapatan Daerah (Bapenda) Kabupaten Karawang".

\section{Tinjauan Pustaka}

Pengembangan Karir

Menurut Gary Dessler (2007, h : 5) pengembangan karir didefinisikan sebagai : "Serangkaian aktivitas sepanjang hidup (seperti workshop) yang berkontribusi pada eksplorasi, pemantapan, keberhasilan, dan pencapaian karier seseorang".

Andrew J. Fubrin dalam A.A. Anwar Prabu Mangkunegara (2006,h.77) menyatakan bahwa : "Pengembangan karier adalah aktivitas kepegawaian yang membantu pegawaipegawai merencanakan karier masa depan mereka diperusahaan agar perusahaan dan pegawai yang bersangkutan dapat mengembangkan diri secara maksimal.

Definisi lain dikemukakan oleh Sadili Samsudin (2006,h.133) menyatakan: "Pengembangan karier adalah suatu kondisi yang menunjukkan adanya peningkatan status seseorang dalam suatu organisasi pada jalur karier yang telah ditetapkan dalam organisasi yang bersangkutan". Dimana pengembangan karier tersebut meliputi berbagai kegiatankegitan personal yang dilakukan untuk mencapai sebuah rencana karier (Safri Mangkuprawira,2004,h.188).

Dari berbagai definisi di atas dapat diambil kesimpulan bahwa pengembangan karier menunjukkan pada perkembangan secara individu dalam jenjang kepangkatan dan jabatan yang dapat dicapai selama masa tertentu dalam suatu organisasi atau perusahaan. Pengembangan karier tiap karyawan tentu antara satu dengan yang lainnya tidak sama karena banyak faktor yang mempengaruhinya. Dimana keberhasilan karier individu dipengaruhi oleh fakor-faktor seperti : pendidikan formal, pengalaman kerja, sikap atasan, pestasi kerja, bobot pekerjaan, lowongan jabatan dan produktivitas kerja.

\section{Dimensi dan Indikator Pengembangan Karir}

Dimensi dan indikator pengembangan karir menurut Sadili Samsudin (2006:hal.133) yaitu terdiri atas beberapa hal :

1. Pengembangan Karir Individu dengan indikator prestasi kerja, exposure, Kesetiaan terhadap organisasi, Mentor dan sponsor,

2. Pengembangan karir yang didukung departemen SDM dengan indikatornya adalah peluang untuk tumbuh dan kesempatan

\section{Motivasi Kerja}

Motivasi merupakan salah satu hal yang mempengaruhi perilaku manusia, motivasi disebut juga sebagai pendorong, keinginan, pendukung atau kebutuhan-kebutuhan yang dapat membuat seseorang bersemangat dan termotivasi untuk mengurangi serta memenuhi dorongan diri sendiri.

Menurut Veithzal (2005: 455-456) Motivasi adalah serangkaian sikap dan nilai yang mempengaruhi individu untuk mencapai hal yang spesifik sesuai dengan tujuan individu. Sikap dan nilai tersebut merupakan suatu yang invisible yang memberikan kekuatan untuk mendorong individu bertingkah laku dalam mencapai tujuan.

Menurut Siswanto (2005, hal.119) motivasi dapat diartikan sebagai keadaan kejiwaan dan sikap mental manusia yang memberikan energi, mendorong kegiatan (moves) dan mengarah atau menyalurkan perilaku kearah mencapai kebutuhan yang memberi

4. 
kepuasan atau mengurangi ketidakseimbangan. Kebutuhan tersebut timbul akibat adanya berbagai hubungan. Kebutuhan dapat berwujud fisik bilogis serta sosial ekonomis. Akan tetapi yang lebih penting adalah adanya kebutuhan (needs) yang bersifat sosial psikis, misalnya penghargaan, pengakuan, keselamatan, perlindungan, keamanan, jaminan sosial, dan sebagainya. Jadi secara singkat motivasi diartikan sebagai bagian integral dan hubungan perburuan dalam rangka proses pembinaan, pengembangan, dan pengarahan sumber daya manusia.

\section{Dimensi dan Indikator Motivasi Kerja}

Motivasi adalah suatu faktor yang mendorong untuk melakukan suatu aktifitas tertentu. Dimensi dan indikator menurut Mc. Clelland's (dalam Melayu Hasibuan 2005;141), sebagai berikut :

1. Kebutuhan untuk mencapai prestasi dengan indikatornya sebagai berikut: kebutuhan ekonomis, nyaman bekerja dan adanya kebijakan atasan.

2. Kebutuhan untuk berafiliasi dengan indikatornya sebagai berikut : kerja yang menyenangkan dan disiplin waktu kerja.

3. Kebutuhan akan kekuasaan dengan indikatornya sebagai berikut : mendapat gaji yang sepadan, adanya penghargaan prestasi kerja dan pemberian bonus.

\section{Kepuasan Kerja}

Setiap orang yang bekerja mengharapkan memperoleh keputusan dari tempat kerjanya. Kepuasan kerja akan mempengaruhi produktivitas yang sangat diharapkan manajer untuk itu manajer perlu memahami apa yang harus dilakukan untuk menciptakan kepuasan kerja karyawannya menjadi pelaku yang menunjang tercapainya tujuan, mempunyai pikiran, perasaan dan keinginan yang dapat mempengaruhi sikap-sikapnya terhadap pekerjaannya. Sikap ini akan menentukan berprestasi kerja, dedikasi dan kecintaan pekerjaannya.Yang dibebankan kepadanya.

Torrington (1998 : 304) mengungkapkan bahwa "job satisfaction refers basically to how much employers like their job". Kepuasan kerja akan muncul apabila seseorang menyukai pekerjaannya, dan sebaliknya seseorang akan merasa tidak puas apabila pekerjaan yang ia kerjakan adalah bukan pekerjaan yang ia sukai.

Luthans (2002 : 230) mengutip tulisan Locke (1976 : 1300) bahwa "Jobs satisfactions as a pleasureable or positive emotional state resulting from appraisal of ones job or job experience". (Kepuasan kerja adalah keadaan emosi yang menyenangkan atau positif yang merupakan hasil dari prestasi kerja atau pengalaman).

Mcshane and Von Glinow dalam Sihol Sitongkir (2005:163), bahwa kepuasan adalah sikap dan perasaan umum pegawai atas pekerjaannya. faktor kepuasan kerja terdiri dari: activity, compensation, independence, recognition, sosial service, sosial status.

\section{Dimensi dan Indikator Kepuasan Kerja}

Adapun dimensi dan indikator kepuasan kerja menurut Luthans (2002 : hal.230) adalah sebagai berikut :

1. Pekerjaan itu sendiri, dengan indikatornya adalah senang dengan tugas yang dipegangnya dan senang dengan kesesuaian bidangnya.

2. Penggajian, dengan indikatornya adalah gaji yang diterima dan insentif yang diterima.

3. Promosi, dengan indikatornya adalah kesempatan mendapatkan kenaikan jabatan

4. Pengawasan, dengan indikatornya adalah mendapatkan pengawasan dan penghargaan

5. Teman Sejawat, dengan indikatornya adalah memberikan bantuan. 


\section{Kinerja Pegawai}

Kinerja merupakan penampilan hasil karya seseorang dalam bentuk kualitas ataupun kuantitas dalam suatu organisasi. Kinerja dapat merupakan penampilan individu maupun kelompok kerja pegawai. Penentuan tujuan setiap unit organisasi merupakan strategi untuk meningkatkan kinerja.

Kinerja dapat didefinisikan sebagai hasil kerja konkrit yang sistematik atau rasio hasil kerja nyata dengan standar yang telah ditetapkan, baik kualitas maupun kuantitas serta waktu dan biaya yang dihasilkan pegawai dalam kurun waktu tertentu untuk mewujudkan hasil. Penilaian prestasi kerja PNS terdiri atas unsur sasaran kerja pegawai dan unsur perilaku kerja. Sasaran Kerja Pegawai yang selanjutnya disingkat SKP adalah rencana kerja dan target yang akan dicapai oleh Pegawai Negeri Sipil (PNS). (PP 46 Tahun 2011).

A.A. Anwar Prabu Mangkunegara (2004:67), mengatakan : Istilah kinerja berasal dari kata Job Performance atau Actual performance (prestasi kerja atau prestasi sesungguhnya yang dicapai oleh seseorang). Pengertian kinerja (Prestasi kerja) adalah hasil kerja secara kualitas dan kuantitas yang dicapai oleh seseorang pegawai dalam melaksanakan tugasnya sesuai dengan tanggung jawab yang diberikan kepadanya.

\section{Dimensi dan Indikator Kinerja Pegawai}

Adapun dimensi dan indikator kinerja menurut PP No 46 (2011), yaitu :

1. Orientasi pelayanan, dengan indikatornya adalah Sikap dan perilaku PNS dalam memberikan pelayanan terbaik kepada yang dilayani antara lain meliputi masyarakat, atasan, rekan sekerja, unit kerja terkait, dan/atau instansi lain.

2. Integritas, dengan indikatornya adalah Kemampuan untuk bertindak sesuai dengan nilai, norma dan etika dalam organisasi.

3. Komitmen, dengan indikatornya adalah Kemauan dan kemampuan untuk menyelaraskan sikap dan tindakan PNS untuk mewujudkan tujuan organisasi dan mengutamakan kepentingan diri sendiri, seseorang, dan/atau golongan.

4. Disiplin, dengan indikatornya adalah Kesanggupan PNS untuk mentaati kewajiban dan menghindari larangan yang ditentukan dalam peraturan perundang-undangan dan/atau peraturan kedinasan yang apabila tidak ditaati atau dilanggar dijatuhi hukuman disiplin dan Kemauan dan kemampuan PNS untuk bekerja hukuman.

5. Kerjasama, dengan indikatornya adalah Kemampuan bersama dengan rekan sekerja serta instansi lain dalam menyelesaikan suatu tugas dan tanggung jawab yang ditentukan sehingga tercapai daya guna dan hasil guna yang sebesar-besarnya.

6. Kepemimpinan, dengan indikatornya adalah Kemampuan dan kemauan PNS untuk memotivasi dan mempengaruhi bawahan atau orang lain yang berkaitan dengan bidang tugasnya demi tercapainya tujuan organisasi (bagi PNS yang menduduki jabatan struktural)

\section{Hipotesis Penelitian}

Berdasarkan kerangka pemikiran yang telah disajikan di atas, maka dapat diambil hipotesis bahwa diduga :

1. Terdapat korelasi pengembangan karir dengan motivasi kerja

2. Terdapat berpengaruh Pengembangan Karir secara parsial terhadap kepuasan kerja pegawai

3. Terdapat pengaruh Motivasi secara parsial terhadap kepuasan kerja

4. Terdapat berpengaruh Pengembangan Karir secara parsial terhadap kinerja pegawai

5. Terdapat pengaruh Motivasi kerja secara parsial terhadap kinerja pegawai

6. Terdapat pengaruh kepuasan kerja pada kinerja pegawai 
7. Terdapat pengaruh Pengembangan Karir dan motivasi pegawai secara simultan terhadap pada kepuasan kerja

8. Terdapat pengaruh Pengembangan Karir dan motivasi pegawai secara simultan terhadap kepuasan kerja yang berdampak pada kinerja pegawai.

\section{Metodologi Penelitian}

Metode ini menggunakan pendekatan kuantitatif dengan cara menyebarkan kuesioner yang di ajukan kepada seluruh pegawai Badan Pendapatan Daerah (Bapenda) dengan pengolahan data menggunakan progaram SPSS. Sedangkan alat pengujian untuk menganalisis uji verifikatif menggunakan analisis Jalur (path analysis).

\section{Populasi dan sampel}

Populasi dalam penelitian ini adalah seluruh pegawai Badan Pendapatan Daerah Kabupaten Karawang yang berjumlah 75 orang. Karena jumlah populasi sebanyak 75 orang, maka sampel yang digunakan sebesar jumlah populasi yang ada. Teknik pengambilan sampel menggunakan teknik sensus.

\section{Jenis dan Sumber Data}

Data adalah segala sesuatu yang diketahui atau dianggap mempunyai sifat bias memberikan gambaran tentang suatu keadaan atau persoalan (Supranto, 2001). Data yang digunakan dalam penelitian ini meliputi adalah data Primer. Data primer yang ada dalam penelitian ini merupakan penyebaran kuesioner.

\section{Uji Keabsahan Data}

Konsep untuk mengukur kualitas data, yaitu validitas dan reliabilitas. Penelitian akan menghasilkan kesimpulan yang tepat jika datanya valid dan reliable. Suatu instrumen yang reliable belum tentu valid, karenanya reliabilitas instrumen merupakan syarat untuk pengujian validitas instrumen. Oleh karena itu instrumen yang valid umumnya reliable, tetapi pengukuran reliabilitas instrumen perlu dilakukan.

Dengan kualitas data yang baik maka data yang terkumpul benar-benar menggambarkan fenomena yang ingin diukur. Sehingga dengan menggunakan instrumen yang valid dan reliable, maka hasil penelitian dapat dipertanggungjawabkan secara ilmiah.

\section{Rancangan Analisis Data}

Rancangan analaisis data untuk menggambarkan atau mendeskripsikan kondisi variable pengembangan karir $\left(\mathrm{X}_{1}\right)$, Motivasi $\left(\mathrm{X}_{2}\right)$ terhadap Kepuasan Kerja $(\mathrm{Y})$ dan berdampak pada Kinerja Pegawai $(\mathrm{Z})$ dengan menggunakan analisis desktiptif rentang skala dan analisis verifikatif menggunakan analisis korelasi, determinasi dan path analysis. Selanjutnya dilakukan uji hipotesis dengan menggunakan uji $\mathrm{t}$ dan uji $\mathrm{F}$.

\section{Hasil dan Pembahasan Analisis Deskriptif}

Total keseluruhan dari kuesioner tentang pengembangan karir yang dibagikan kepada 75 responden menghasilkan angka sebesar 1.323 dengan rata-rata sebesar 221. Angka tersebut berada pada interval pernyataan cukup setuju.Hal ini berarti bahwa pegawai cukup setuju terhadap pola pelaksanaan pengembangan karir saat ini di Bapenda Karawang.

Total keseluruhan dari kuesioner tentang motivasi kerja ini yang dibagikan kepada 75 responden menghasilkan angka sebesar 1.989 dengan rata-rata sebesar 249. Angka tersebut 
berada pada interval pernyataan cukup setuju. Hal ini berarti bahwa pegawai cukup setuju terhadap pola pelaksanaan motivasi yang dilakukan oleh Bapenda Karawang.

Total keseluruhan dari kuesioner tentang kepuasan kerja pegawai ini yang dibagikan kepada 75 responden menghasilkan angka sebesar 2.034 dengan rata-rata sebesar 254 . Angka tersebut berada pada interval pernyataan cukup setuju.Hal ini berarti bahwa pegawai cukup setuju terhadap kepuasan kerja yang terjadi saat ini.

Total keseluruhan dari kuesioner tentang kinerja ini yang dibagikan kepada 75 responden menghasilkan angka sebesar 1.406 dengan rata-rata sebesar 234. Angka tersebut berada pada interval pernyataan cukup setuju. Hal ini berarti bahwa pegawaicukup setuju terhadap pola yang dilakukan oleh Bapenda Karawangdalam upaya meningkatkan kinerja pegawainya.

\section{Analisis Verifikatif \\ Analisis Korelasi}

Dari hasil analisis diperoleh besaran koefisien korelasi diantara variabel bebas yaitu pengembangan karir pegawai dengan motivasi kerja sebesar 0,350. Dengan demikian korelasi pengembangan karir pegawai dengan motivasi kerja memiliki tingkat korelasi yang rendah dan nilainya positif dikarenakan berada di interval koefisien nilai $0,200-0,399$ : tingkat hubungan yang rendah. (Sugiyono, 2000:255).

\section{Analisis Jalur}

\section{Koefesien Jalur Antar Variabel}

\section{a. Koefesien Jalur Variabel X Terhadap Y}

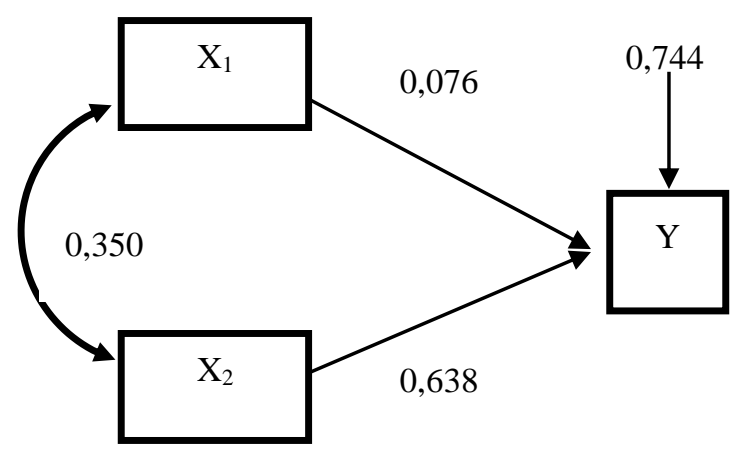

Dalam perhitungan tersebut diperoleh kontribusi dari variabel lain sebesar 0,744 atau $74,40 \%$. Artinya bahwa pengaruh variable lain yang tidak dipakai dalam penelitian ini sebesar $74,40 \%$. Sehingga bentuk persamaan pertama adalah : $\mathrm{Y}=0,076 \mathrm{X}_{1}+0,638 \mathrm{X}_{2}+$ 0,744 .

\section{b. Koefesien Jalur Variabel X Terhadap Z}

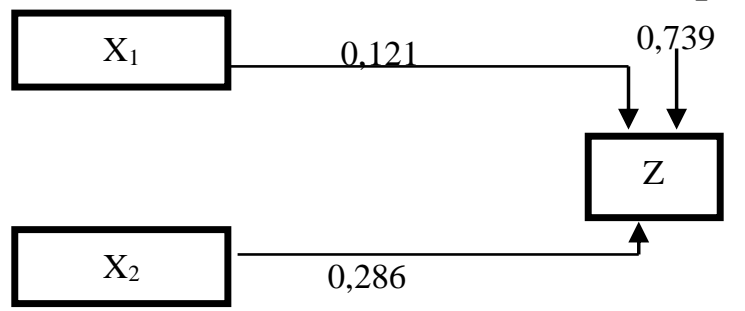

8. 
Dalam perhitungan tersebut diperoleh kontribusi dari variabel lain sebesar 0,739 atau $73,90 \%$. Artinya bahwa pengaruh variable lain yang tidak dipakai dalam penelitian ini sebesar 73,90\%. Sehingga bentuk persamaan pertama adalah : $Z=0,121 X_{1}+0,286 X_{2}+$ 0,739 .

\section{c. Koefesien Jalur Variabel Y Terhadap Z}

Koefesien jalur variabel kepuasan kerja pegawai $\left(\mathrm{X}_{2}\right)$ terhadap kinerja pegawai $(\mathrm{Z})$ sebesar 0,394.

\section{Pembahasan}

\section{Pengembangan Karir}

Pengembangan karir pegawai memiliki 6 indikator berada pada rentang nilai $195-255$ dengan nilai skor 221 dan berada pada kriteria cukup setuju, artinya pelaksanaan pengembangan karir di Bapenda Karawang dinilai oleh pegawai kurang baik dilaksanakan. Atau dapat dikatakan bahwa pola pelaksanaan pengembangan karir pegawai yang dilakukan sekarang ini belum sesuai dengan standar baku tentang pengembangan karir pegawai yang sudah ditetapkan.

\section{Motivasi Kerja}

Motivasi kerja memiliki 8 indikator yang berada pada rentang nilai 195 - 255.Total keseluruhan dari kuesioner tentang motivasi kerja ini yang dibagikan kepada 75 responden menghasilkan angka sebesar 1.989 dengan rata-rata sebesar 249. Dan angka tersebut berada pada interval pernyataan cukup setuju. Artinya bahwa apa yang dilakukan oleh Bapenda Karawang dalam upaya mendorong dan memotivasi pegawainya belum baik dilakukan seluruhnya.

\section{Kepuasan Kerja}

Kepuasan kerja memiliki 8 indikator yang berada pada interval $195-255$. Dengan total nilai skor sebesar 2.034 dan nilai rata-rata sebesar 254. Nilai tersebut berada pada kriteria jawaban responden cukup setuju.Artinya bahwa apa yang dilakukan oleh Bapenda Karawang saat ini belum mampu memberikan kepuasan kepada para pegawainya dalam melaksanakan pekerjaan.

\section{Kinerja Pegawai}

Kinerja memiliki 6 indikator yang berada pada skala nilai 195 - 255 dengan kriteria cukup setuju terhadap peningkatan kinerja, artinya Bapenda Karawang dalam meningkatkan kinerja pegawainya belum sesuai dengan prosedur yang sudah ada dan ditetapkan oleh pihak perusahaan sendiri.

\section{Korelasi Pengembangan Karir dengan motivasi kerja}

Dari hasil analisis yang diperoleh didapat besaran koefisien korelasi antara variabel pengembangan karir dengan motivasi kerja yaitu sebesar 0,350. Dengan demikian korelasi pengembangan karir dengan motivasi kerja memiliki tingkat korelasi yang rendah dan nilainya positif dikarenakan berada di interval koefisien nilai $0,200-0,399$ : Korelasi rendah (Sugiyono, 2000:255).

\section{Pengaruh Parsial Pengembangan Karir Terhadap Kepuasan Kerja}

Hasil penelitian menunjukan bahwa pengembangan karir berpengaruh signifikan terhadap kepuasan kerja sebesar 0,0184 atau 1,84\%. Dan berdasarkan uji hipotesis dengan 
tingkat signifikan $(\alpha)=5 \%$, diperoleh nilai $\mathrm{t}_{\text {hitung }}(0,813)<\mathrm{t}_{\text {tabel }}(1,666)$ dan tingkat signifikansi sebesar 0,419. Dimana 0,419 lebih besar dari 0,05. Hal ini berarti pengembangan karir memiliki pengaruh yang kurang signifikan terhadap kepuasan kerja pegawai pada Bapenda Karawang.Namun bukan berarti bahwa pengembangan karir dilakukan secara tidak normatif saat ini, karena pengembangan karir masih memiliki pengaruh meskipun dalam upaya peningkatan kepuasan kerja pengaruhnya kecil.

\section{Pengaruh Parsial Motivasi Kerja Terhadap Kepuasan Kerja}

Hasil penelitian menunjukan bahwa motivasi kerja berpengaruh signifikan terhadap kepuasan kerja sebesar0,4196 atau 41,96\%. Dan berdasarkan uji hipotesis dengan tingkat signifikan $(\alpha)=5 \%$, diperoleh nilai $t_{\text {hitung }}(6,819)>t_{\text {tabel }}(1,666)$ dantingkatsignifikansebesar 0,000. Dimana 0,000 lebihkecildari 0,05. Hal iniberarti motivasi kerja berpengaruhsignifikanterhadap kepuasan kerja pegawai pada Bapenda Karawang.

\section{Pengaruh Parsial Pengembangan Karir Terhadap Kinerja Pegawai}

Hasil penelitian menunjukan bahwa pengaruh pengembangan karir terhadap kinerja pegawai sebesar 0,0182 atau $1,82 \%$. Dan berdasarkan uji hipotesis dengan tingkat signifikan $(\alpha)=5 \%$, diperoleh nilai $t_{\text {hitung }}(1,289)<t_{\text {tabel }}(1,666)$ dantingkatsignifikansebesar 0,202. Dimana 0,202 lebih besar dari 0,05Artinya bahwa pengembangan karir kurang berpengaruh secara signifikan terhadap kinerja pegawai. Ini berarti bahwa terdapat kekurangan atau pelaksanaan pengembangan karir yang dijalankan kurang sesuai dengan harapan.

\section{Pengaruh Motivasi Kerja Terhadap Kinerja Pegawai}

Hasil penelitian menunjukan bahwa motivasi kerja berpengaruh signifikan terhadap kinerja pegawai sebesar0,1537 atau 15,37\%. Dan berdasarkan uji hipotesis dengan tingkat signifikan $(\alpha)=5 \%$,diperoleh nilai $t_{\text {hitung }}(2,380)>t_{\text {tabel }}(1,666)$ dan tingkat signifikan sebesar 0,020. Dimana thitunglebih besar dari tabel. Hal ini berarti motivasi kerja berpengaruh signifikan terhadap kinerja pegawai pada Bapenda Karawang.

\section{Pengaruh Kepuasan Kerja Terhadap Kinerja Pegawai}

Hasil penelitian menunjukan bahwa motivasi kerja berpengaruh signifikan terhadap kepuasan kerja sebesar0,1552 atau 15,52\%. Dari hasil uji hipotesis dengan alfa 5\%, diperoleh nilai signifikansi sebesar 0,001. Dimana 0,001 lebih kecil dari 0,05. Hal ini berarti kinerja berpengaruh signifikan terhadap kepuasan kerja pegawai pada bapenda Karawang.Pada umumnya orang mengharapkan bahwa faktor tertentu memberikan kepuasan. Kepuasan kerja merupakan variabel yang menunjukkan ada hubungan dengan faktor kinerja.

\section{Pengaruh simultan pengembangan karir dan motivasi kerja terhadap kepuasan kerja}

Dari hasil perhitungan dalam penelitian ini, diperoleh nilai pengaruh simultan sebesar 0,4380 atau $43,80 \%$. Artinya bahwa kontribusi variabel pengembangan karir dan motivasi kerja terhadap kepuasan kerja sebesar 43,80\%, sedangkan sisanya sebesar $56,20 \%$ dipengaruhi faktor lain yang tidak diteliti dalam penelitian ini.

12. Pengaruh simultan pengembangan karir dan motivasi kerja terhadap kepuasan kerja yang berdampak pada kinerja pegawai 
Dari hasil perhitungan dalam penelitian ini, diperoleh nilai pengaruh simultan sebesar 0,3271 atau $32,71 \%$. Artinya bahwa kontribusi variabel pengembangan karir dan motivasi kerja terhadap kepuasan kerja yang berdampak pada kinerja pegawai yaitu sebesar $32,71 \%$, sedangkan sisanya sebesar $67,30 \%$ dipengaruhi faktor lain yang tidak diteliti dalam penelitian ini.

\section{Simpulan}

Berdasarkan hasil penelitian yang dilakukan pada Bapenda Karawang maka dapat disimpulkan hal-hal sebagai berikut :

1. Pengembangan karir pada Bapenda Karawang berada pada rentang skala cukup setuju. Artinya bahwa pegawai cukup setuju terhadap pola pelaksanaan pengembangan karir saat ini di Bapenda Karawang. Hal ini dibuktikan dari hasil penelitian dimana nilai skor variabel pengembangan karir mempunyai total skor 1.323 dengan rata-rata sebesar 221 .

2. Motivasi kerja pada Bapenda Karawang berada pada rentang skala cukup setuju. Artinya bahwa pegawai cukup setuju terhadap pola pelaksanaan motivasi yang dilakukan oleh Bapenda Karawang. Hal ini dibuktikan dari hasil penelitian tentang variabel motivasi kerja dimana total nilai skor yang diperoleh sebesar 1.989 dengan ratarata sebesar 249.

3. Kepuasan kerja pegawai pada Bapenda Karawang berada pada rentang skala cukup setuju. Artinya bahwa pegawai cukup setuju terhadap kepuasan kerja yang terjadi saat ini. Hal itu dibuktikan dengan total nilai skor yang dihasilkan sebesar 2.034 dengan ratarata skor sebesar 254 .

4. Kinerja pegawai pada Bapenda Karawang berada pada rentang skala cukup setuju. Artinya bahwa pegawai cukup setuju terhadap pola yang dilakukan oleh Bapenda Karawang dalam upaya meningkatkan kinerja pegawainya. Hal ini dibuktikan dengan total nilai skor yang diperoleh sebesar 1.406 dengan rata-rata sebesar 234 .

5. Korelasi pengembangan karir dengan motivasi kerja mempunyai nilai koefesien korelasi (r) sebesar 0,350. Dengan demikian korelasi pengembangan karir dengan motivasi kerja memiliki tingkat korelasi rendah karena berada pada koefisien nilai $0,200-0,399$ : tingkat hubungan yang rendah (Sugiyono:2014:184) dan nilainya positif. Ini menunjukan bahwa jika pengembangan karir dengan motivasi kerja mampu meningkatkan kinerja pegawai jika dilakukan sesuai dengan prosedur yang baik dan benar.

6. Pengaruh pengembangan karir terhadap kepuasan kerja pegawai sebesar 0,0184 atau $1,84 \%$. Berdasarkan uji hipotesis yang menyatakan bahwa "pengembangan karir berpengaruh secara signifikan terhadap kepuasan kerja pegawai” ditolak. Artinya bahwa pengembangan karir kurang berpengaruh dalam peningkatan kepuasan kerja pegawai di Bapenda Karawang.

7. Pengaruh motivasi kerja terhadap kepuasan kerja pegawai sebesar 0,4196 atau $41,96 \%$. Berdasarkan uji hipotesis yang menyatakan bahwa "motivasi kerja berpengaruh secara signifikan terhadap kepuasan kerja pegawai" diterima. Artinya bahwa motivasi kerja berpengaruh signifikan dalam peningkatan kepuasan kerja pegawai di Bapenda Karawang.

8. Sedangkan pengaruh pengembangan karir terhadap kinerja pegawai sebesar 0,0182 atau $1,82 \%$. Berdasarkan uji hipotesis yang menyatakan bahwa "pengembangan karir berpengaruh secara signifikan terhadap kinerja pegawai" ditolak. Artinya bahwa pengembangan karir kurang berpengaruh dalam peningkatan kinerja pegawai di Bapenda Karawang.

9. Pengaruh motivasi kerja terhadap kinerja pegawai sebesar 0,1537 atau $15,37 \%$. Berdasarkan uji hipotesis yang menyatakan bahwa "motivasi kerja berpengaruh secara 
signifikan terhadap kinerja pegawai" diterima. Artinya bahwa motivasi kerja berpengaruh signifikan dalam peningkatan kinerja pegawai di Bapenda Karawang.

10. Pengaruh kepuasan kerja terhadap kinerja pegawai sebesar 0,1552 atau $15,52 \%$ artinya bahwa peningkatan kepuasan kerja yang berdampak pada peningkatan kinerja pegawai Bapenda Karawang dapat dibuktikan sebesar 15,52\%. Hal ini berarti kepuasan kerja berpengaruh signifikan terhadap peningkatan kinerja pegawai pada Bapenda Karawang.

11. Secara simultan pengembangan karir dan motivasi berpengaruh secara signifikan terhadap kepuasan kerja sebesar 43,80\%. Sisanya yaitu sebesar 56,20\% merupakan pengaruh yang datang dari faktor lain. Hasil uji hipotesis yang menyatakan bahwa "pengembangan karir dan motivasi kerja berpengaruh secara signifikan terhadap kepuasan kerja pegawai" diterima.

12. Secara simultan pengembangan karir dan motivasi kerja berpengaruh secara signifikan terhadap kepuasan kerja yang berdampak pada peningkatan kinerja pegawai sebesar $32,71 \%$. Sisanya yaitu sebesar $67,30 \%$ merupakan pengaruh yang datang dari faktor lain. Berdasarkan temuan penelitian ini disimpulkan bahwa hipotesis penelitian yang menyatakan pengembangan karir dan motivasi kerja berkontribusi secara simultan dan signifikan terhadap kinerja melalui kepuasan kerja pegawai dapat diterima.

\section{Saran}

Berdasarkan hasil pembahasan dan kesimpulan penelitian ini, maka disarankan hal-hal sebagai berikut :

1. Dalam pelaksanaan pengembangan karir, sebaiknya Bapenda Karawang memperhatikan prestasi kerja para pegawai dan bukan karena kedekatan atau balas budi dalam pola pelaksanaan pengembangan karir. Sebab dengan sistem pengembangan karir bagi para pegawai dilaksanakan baik atau sesuai dengan prosedur seperti adanya uji kompetensi, pertimbangan dalam disiplin kerja, loyalitas kepada organisasi dan lain sebagainya, maka hasilnya pun akan memuaskan dan secara langsung akan berdampak pada kinerja pegawai itu sendiri sehingga beban kerja yang di tugaskan mampu terselesaikan dengan baik.

2. Pemberian motivasi kepada pegawai, hendaknya Bapenda Karawang memberikan penghargaan kepada pegawai yang berprestasi dalm bekerja, sebab dengan pemberian penghargaan tersebut dampaknya akan terasa pada motivasi bekerja para pegawai itu sendiri. Sebab mereka merasa diperhatikan oleh instansi atau badan terkait pekerjaannya.

3. Dalam peningkatan kepuasan kerja pegawai, sebaiknya Bapenda Karawang melakukan penyesuaian kembalkat besaran insentif yang diterima oleh pegawai, karena dengan pemberian insentif yang sesuai dengan beban pekerjaan pegawai, maka pegawai diharapkan agar bisa lebih giat lagi dalam bekerja.

4. Dalam upaya peningkatan kinerja karyawan, sebaiknya seluruh pegawai pada Badan Pendapatan Daerah Karawang mengedepankan kerjasama antar rekan sekerja dalam upaya menyelesaikan pekerjaannya guna mencapai hasil guna yang sebesar-besarnya. Karena dengan kerjasama pekerjaan apapun akan lebih mudah dikerjakan.

5. Penelitian lebih lanjut tentang variabel lainnya yang mempengaruhi variabel kinerja melalui kepuasan kerja pegawai pada Bapenda Karawang yang tidak diteliti dalam penelitian ini sehingga diharapkan fungsi dan sistem manajemen dapat berjalan lebih optimal. 


\section{Daftar Pustaka}

AA Anwar Prabu M, 2004. Manajemen Sumber Daya Manusia Perusahaan. Remaja Rosda karya, Bandung.

Arfin Murti, (2012). "Menciptakan Sumber Daya Manusia Yang Handal Dengan Training, Coaching dan Motivation”. Sidoarjo :LaskarAksara.

Arikunto, Suharsimi. (2006). “Prosedur Penelitian, Suatu pendekatan Praktek”. Jakarta: Rineka Cipta

Amirullah \& Haris Budiyono. 2004. Pengantar Manajemen. Yogyakarta :Graha Ilmu.

Anoraga, Pandji. 2000. Psikologi Kepemimpinan. Jakarta: Rineka Cipta.

As'ad, M. (2003), Psikologi Industri: Seri Sumber Daya Manusia, Liberty, Jogjakarta.

----------. 2004. Psikologi Industri. Yogyakarta: Liberty

Cassio, Wayne F, 1998. Applied Psychology In Human Resource Management, Prentice Hall.

Edwin B_Flippo, 1996.Manajemen Personalia, Alih Bahasa Moh. Masud, Erlangga.

Edy Sutrsino, 2009. Manajemen Sumber Daya Manusia. Kencana, Jakarta.

Faustine Cardoso Gomes, 1995. Manajemen Sumber Daya Manusia, Andi, Yogyakarta.

Husen Umar, 2005. Riset Sumber Daya Manusia Dalam Organisasi. Gramedia Pustaka Utama, Jakarta.

Istijanto, 2006. Riset Sumber Daya Manusia, Gramedia Pustaka Utama., Jakarta.

James L Gibson, dkk. 1996. Organisasi (Perilaku, Struktur, Proses) Bina rupa Aksara, Jakarta.

Kusnendi, 2005.Analisis Jalur Konsep dan Aplikasi dengan Program SPSS dan Lisrel 8, Penerbit Jurusan Pendidikan Ekonomi - UPI.

Mathis, Robert. L dan Jackson, John.H. (2001). Manajemen Sumber Daya Manusia (Jilid 1). Penerbit - Salemba Empat-Jakarta.

Mathis, Robert. L dan Jackson, John.H. (2001). Manajemen Sumber Daya Manusia (Jilid 2). Penerbit: Salemba Empat-Jakarta.

Milkovich, George. T dan Newman, Jerry.M.(2002). Compensation.McGraw-Hill Companies-North America.

Moekijat, 1995. Manajemen Personalia Dan Sumber Daya Manusia, Mandar Maju, Bandung.

Sedarmayanti, 2004. Pengembangan Kepribadian Pegawai. Mandar Maju, Bandung.

Sidik Priadana, 2005, Panduan Penyusunan Skripsi Dan Tesis. STIE Pasundan.

Sondang P. Siagian, 1995. Teori Motivasi Dan Aplikasinya. Rineka Cipta, Jakarta.

Jakarta.

Sudjana, 2002. Teknis Analisis Regresi dan Kolerasi, Tarsito, Bandung.

Suharsimi Arikunto, 1997. Prosedur Penelitian Suatu Pendekatan Praktek, Rineka Cipta, Jakarta.

2005. Manajemen Penelitian, Rineka Cipta. Jakarta

Stephen P. Robbins, 1996. Prilaku Organisasi, Prenhall indo, Jakarta

Stephen P. Robbins \& Mary Coulter, 2004. Manajemen, PT Indeks Kelompok Gramedia, Jakarta.

Sugiyono, 2003. Teknik Analisis Regresi dan Kolerasi. Tarsito, Bandung.

--.-.- 2003.Metode Penelitian Bisnis. CV Alphabeta, Bandung.

Veithzal Rival, 2005. Manajemen Sumber Daya Manusia Untuk Perusahaan Dari Teon ke Praktik, PT Raja Grafindo Persada, Jakarta.

William B. Werther, and Keith Davis, 2003. Human Resoursces And Personnel Management, McGraw Hill Higher Education. 
Wixley, Kenneth, and Yuki Gari, 1992. Prilaku Organisasi.

1997. Organizational Behavior and Personnel Psychology.

Sadeli Samsudin $(2006 ; 18)$ dalam bukunya Manajemen Sumber Daya Manusia.

Suwatno (Unpad, 2007). Pengaruh komunikasi organisasi dan budaya organisasi terhadap motivasi berprestasi serta implikasinya terhadap kinerja.

Srikitiarti (Tesis, 2010). Pengaruh Kepemimpinan dan Motivasi Kerja terhadap kepuasan kerja implikasinya pada Kinerja Diskoperindagtan Kota Cimahi.

Engkus Kusnadi (Tesis Upad, 2006). Pengaruh kompetensi,Pengembangan Karier, dan budaya organisasi terhadap kinerja Pegawai Dinas Pendapatan Daerah Kota Bandung.

Edi Suryadi (2004). Studi Tentang Komunikasi, Motivasi dan Budaya Organisasi Serta pengaruhnya Terhadap kinerja dan dampaknya terhadap produktivitas Kerja (Pada BUMN Sektor Jasa Di jawa Barat).

Zulkarnain (tesis, 2004). Pengaruh budaya organisasi dan iklim organisasi terhadap kinerja karyawan pada BUMN sektor Jasa Jawa Barat.

Undang-undang Republik IndonesiaNomor 43 tahun 1999.Tentang Pokok-Pokok Kepegawaian.

Undang-undang Republik Indonesia Nomor 5 Tahun 2014. Tentang Aparatur Sipil Negara (ASN).

PeraturanPemerintah RI Nomor 13 Tahun 2002. Tentang Pengangkatan Pegawai Negeri Sipil Dalam Jabatan Struktural.

Peraturan Pemerintah RI Nomor 46 Tahun 2011 tentang Penilaian Prestasi Kerja Pegawai Negeri Sipil.

Peraturan Kepala Badan Kepegawaian Negara Nomor 35 Tahun 2011.Pengaturan Tata Cara Pengembangan Karier.

\section{Sumber Jurnal :}

Ermayanti Dwi, Thoyib Armanu, 2001. Pengaruh Faktpr Motivasi Terhadap Prestasi Kerja Karyawan Pada Kantor Perum Perhutani II Surabaya, Jurnal Fakultas Ekonomi Universitas Brawijaya Malang. FaridYuli,2011.Pengaruh Motivasi Kerja Kepemimpinan dan Budaya Organisasi terhadap Kinerja Karyawan (Studi Kasus di PDAM Ekskarisidenan Surakarta).

Rezki Ramadhanni, 2014, Pengaruh Pelaksanaan Promosi Jabatan Terhadap Semangat Kerja Karyawan Divisi Redaksi Pada Pt. Tribun Pekanbaru. Jurnal FISIP Volume 2 No. 2 Oktober 2014.

Sugisno.Pengaruh Motivasi Kerja Terhadap Kinerja Perusahaan dan Pencapaian Individu di Best Western Hotel Asean International Medan Sumatera Utara. Jurnal. (tidak dipublikasikan).

Tampubolon, Biatna. D. 2007. Analisis Gaya Kepemimpinan dan Faktor Etos Kerja Terhadap Kinerja Pegawai Pada Organisasi yang Telah Menerapkan SNI 19-90012001. Jurnal Standardisasi No. 9, Hal: 106-115.

Pradana, Martha A., Bambang Swasto, D. Hamid. 2013. Pengaruh gaya kepemimpinan transformasional dan transaksional terhadap kinerja karyawan. Jurnal Administrasi Bisnis, 4 (1) : 4

Yahyo, Handoyo Djoko W \& Reni Shinta Dewi, 2013 , Pengaruh Motivasi Lingkungan Kerja, dan Kompensasi terhadap kinerja karyawan 88 melalui semangat kerja karyawan (Studi Kasus pada karyawan Melalui produksi CV. Putra Jaya Sahitaguna, Semarang), Diponegoro Journal of social and politic Tahun 2013, Hal $1-12$. 